\title{
FACTORS HINDERING THE SUCCESSFUL OUTCOME OF RURAL COMMUNITY PROJECTS
}

\section{MDM Makofane, MMA Gray}

\section{INTRODUCTION}

Limpopo Province occupies $10 \%$ of South Africa's land mass and has $11.9 \%$ of the population. It is one of the poorest of the nine provinces in South Africa, second to KwaZulu-Natal. It is predominantly rural in nature. According to the estimates based on the South Africa Survey (South African Institute of Race Relations (SAIRR), 2003-2004), its population is 5.5 million and almost $90 \%$ of residents live in rural areas with $60 \%(3.3 \mathrm{~m})$ of the population living in poverty. The abject poverty that characterises many rural communities in Limpopo, as well as in the rest of South Africa, poses an enormous challenge to the developmental welfare system given its avowed mission to eradicate poverty. The government remains committed to improving the quality of life of South Africans through the initiation of poverty-alleviation projects, especially in rural communities. While rural development remains on the country's agenda, accessing government funding for community development projects is complex, particularly to rural dwellers as a detailed business plan is required. Brown (1999:148) made a similar observation in Transkei (East Cape Province) and concluded that the "most backward and needy areas are less likely...to make a successful application."

\section{CHALLENGES FOR RURAL COMMUNITY DEVELOPMENT}

People are motivated by a wide range of factors to initiate or participate in development projects. There are residents and outsiders who are keen to make a positive impact on the lives of the disadvantaged, while others are out to exploit the situation for their personal gain. Even though the changing global and local situation obliges impoverished communities to become proactive in enhancing the quality of their lives (Nel \& Binns, 2000:1), appropriate external financial and human resources for the survival and success of rural projects is required. There is general agreement that, even if community-based development projects were to arise from bottom up, they would still need support from external development agencies (Narayan, 1995:20). However, most rural communities do not have the expertise or know-how to assess the credibility of organisations and, therefore, they are vulnerable to exploitation. Hence, some projects have failed as a result of mismanagement of funds, nepotism and "substantial corruption" (Brown, 1999:148).

Among the myriad challenges in establishing and sustaining rural development projects are problems relating to inefficiency and ineffectiveness shown in their failure to manage funds and to achieve their technical, social and financial objectives (Arrossi, Bombarolo, Hardoy, Mitlin, Coscio \& Satterthwaite, 1994:77). Factors impeding the success of rural development projects include political, physical, infrastructural, socio-economic and cultural constraints. Rural areas have poor roads and infrastructure. They lack proper housing, even though $82.4 \%$ of the population lives in formal dwellings, with $4.9 \%$ in informal dwellings and $12.3 \%$ in traditional dwellings. A further 130,577 houses were built with government subsidies between 1994 and 2004. Only $2 \%$ of urban houses are without electricity, while $38.7 \%$ of rural houses are not electrified; $75.5 \%$ of households use electricity for lighting, and $28.3 \%$ for heating; $29.7 \%$ of households still use wood for cooking. There is an insufficient supply of clean water and sanitation facilities with only $11.6 \%$ of households having taps in their dwellings and $82.3 \%$ being without flush or chemical toilet facilities. Only $13.1 \%$ of households have a local authority refuse-removal service. 
There are also insufficient educational facilities: just over a fifth of the population has no education at all, while $80 \%$ of the population is literate. Only $2.7 \%$ have a degree or postgraduate qualification and an additional $4.7 \%$ have a certificate or diploma qualification; $14.3 \%$ have completed grade 12 with a final pass rate of $70 \%$. Of these only $19 \%$ achieve a university education pass rate. The per capita expenditure in schools in 2002-2003 was R4015 (approx. US $\$ 800$ ) and schools had a pupil to teacher ration of 33:1. There are 4,561 schools in Limpopo$17.2 \%$ of the schools in South Africa - for a province with $12.9 \%$ of the population in 2002 and $11.9 \%$ in 2004 - possibly a result of AIDS-related deaths and urban migration as discussed below.

As regards health facilities, almost $68 \%$ of children had been immunised in $2002 ; 11 \%$ of the population was HIV positive and $15.6 \%$ of pregnant women attending antenatal clinics were HIV positive. Life expectancy at birth is 52 years with a projected drop to 42 in 2010 due to the rapid spread of HIV and AIDS (SAIRR, 2003-2004:24). Most people are reliant on the public health system, which is grossly inadequate. Over 650,000 people are HIV positive and only 12,603 hospital beds are currently available.

As a result of the underdevelopment in rural areas people move to the cities placing an immense strain on the resources infrastructure of cities and urban townships. This is exacerbated by the high rate of unemployment, poverty, crime, teenage pregnancy, and the spread of HIV and AIDS. As a result, Limpopo contributes only $3.8 \%$ of South Africa's GDP with only $1.3 \mathrm{~m}$ people almost an equal number of males and females - being economically active; an unemployment rate of $30.6 \%$, with $55.8 \%$ of the Limpopo population not fully engaged in the province's economy (SAIRR, 2003-2004:136-137). This means a large number of people are earning a living in the informal sector or surviving on subsistence agriculture. However, even this is untenable in most rural villages, where people live on arid land, a condition exacerbated by severe drought which is threatening their livestock. Therefore, rural villagers are struggling to survive. It has been widely acknowledged that unemployment increases the vulnerability of poor households, with women bearing the brunt of supporting families in rural communities (Ministry for Welfare and Population Development, 1997:9). Several development projects have attempted to address the plight of women faced with the burden of providing for their children's basic needs, such as food and clothing. Also the social cohesion of rural communities is being eroded by the high rate of crime, which has resulted in a high level of mistrust among villagers. Limpopo has the highest rate of murder $(12.1 \%)$, rape $(76.3 \%)$, aggravated robbery $(56.6 \%)$ and motor vehicle theft $(28.6 \%)$ in South Africa, and the second highest rate of stock theft (35.9\%) (SAIRR, 2003-2004).

Social cohesion is also threatened by power struggles between traditional and political leaders, and this impedes development. Traditional leaders were criticised for their resistance to change, which is exacerbating rural poverty (Makofane \& Nuntsu, 2001). Traditional cultural belief systems, especially witchcraft, pose a serious threat to women's development (Makofane, 1998). Additionally, some cultural practices, such as celebrations for the return of young girls and boys from initiation schools and general meetings called by the chief, require all other activities to be put on hold, regardless of their importance to the community. For instance, should such a meeting be called on a Sunday, church services that coincide with the time of the meeting would not take place.

\section{WELFARE AND DEVELOPMENT}

Limpopo received $23 \%$ of the country's welfare and social development budget, an amount of R5 billion (SAIRR, 2003-2004:314). The South African government's development approach to 
social welfare requires that social workers play a greater role in poverty eradication by promoting the active involvement of people in their own development and by employing a multifaceted and multi-sectoral approach to development through facilitating partnerships between the state and the provincial governments, the private sector, business and all stakeholders in social development.

Progress has yet to be assessed, while rural villagers bemoan the lack of development in their areas. Several social work academics have speculated about the failure of social workers to respond to people's development needs. For example, Lombard (1992:109) claims that failures can be attributed to the fact that the needs and expertise of development recipients "have not been adequately taken into consideration." Botes and Van Rensburg (2000:51) suggested that people's lack of participation in development projects could be the result of past experiences where expectations had not been met. They enumerated nine obstacles to community participation:

- the paternalistic role of development professionals;

- the inhibiting and prescriptive role of the state;

- the exaggeration of development success;

- selective participation;

- hard-issue bias;

- conflicting interest groups within beneficiary communities;

- gate keeping by local elites;

- excessive pressure for immediate results;

- the accentuation of product at the expense of process; and

- the lack of public interest in becoming involved (Botes \& Van Rensburg, 2000:42-51).

Thus many commentators focused on problems with community participation when social workers were, in fact, confused about exactly what they were meant to be doing in developmental welfare. There was vagueness about the term, and the long-range responsibility of government in providing the necessary conditions of sustainable development (Lawn, 2001:17), which rested on equitable and sustainable levels of economic wellbeing (Goodland \& Ledec, 1987:36). Also, it seemed unlikely that the necessary change could be achieved by the increased participation of local people in small-scale community development projects run by reluctant social workers, who lacked credibility (Botes \& Van Rensburg, 2000). How could social workers promote grassroots decision-making and a sense of ownership and pride in small community projects given the magnitude of the problems already described? Thus a study was conducted to shed light on this question from the perspective of social work students - future social workers - living in rural areas.

The broad aim of the study was to engage final-year social work students in an analysis of the factors hampering the progress of rural development projects in their respective communities. The research aimed to gain information about the development projects in rural localities; to identify challenges facing the communities and their impact on the projects' progress; and to provide students with the opportunity to share ideas and suggest possible improvements in service delivery. Three focus group discussions were held and the following questions were addressed: 
1. How would you describe the pace of development in your community?

2. Who initiated development projects in your village?

3. What was the rationale for initiating such projects?

4. What process was followed in the development of projects?

5. What factors have hampered the development and sustainability of your project?

6. What recommendations would you make to the Limpopo Department of Health and Social Development regarding social work service delivery in your area?

The three focus groups each consisted of seven participants $(\mathrm{n}=21) ; 71 \%$ (15) were female and $29 \%$ (6) were male. Their ages ranged between 22 to 32 years, while the mean age for all participants was 23.5 years. Each group met for an hour once a week for three consecutive weeks until saturation was reached within the focus group discussions. These discussions were tape recorded and transcribed. Responses were then analysed through the generation of significant themes and sub-themes. The participants were at liberty to articulate their ideas in any language and most mixed English and African languages.

\section{Pace of community development}

Some students were of the opinion that rural areas were generally neglected and that minimal effort was exerted by provincial government to strengthen local rural communities. While participants agreed that development is a process, they were divided on the pace of development in their respective communities. Some indicated that change was occurring, even though it was slow, and believed that committed political leaders were contributing positively to these changes.

Poultry and vegetable projects have been started in my area. Some are viable while others are on the verge of collapse, because the people lack project management and financial skills, monitoring does not take place and funds are misused. I have also observed that social workers are not involved in most community projects.

Some of the participants argued that development of projects would not succeed in their areas as people seemed disillusioned by the lack of government delivery of essential infrastructure, such as clean water, sanitation, electricity and housing. The delivery of these basic services would encourage communities to initiate and participate in poverty-alleviation projects. Community members have been undermined by not being involved in assessing community needs and, in some areas, needs assessment had not preceded the introduction of development projects. This had contributed to the slow pace of progress. Many projects had been initiated by unscrupulous outsiders who infiltrated rural communities to take advantage of the villagers' dire circumstances by promising them employment. These individuals acted out of self-interest to enrich themselves rather than a desire to respond to the needs and concerns of rural communities. Thus most projects were short-lived and left community members devastated. Such experiences instilled fear and mistrust, hence the community's scepticism towards anyone wanting to initiate new projects in their area. There was also a perception that some project members placed unnecessary pressure on project managers by demanding payment prematurely and this could partly explain the projects' inability to reach the desired outcomes.

Some of the participants stated that an equitable distribution of funds to the projects was rendered impossible by nepotism. They questioned the impartiality of officials from the Department of Health and Social Development in the allocation of funds to community projects. For example, one of the participants stated that: 
You will see a stranger entering your community claiming that $\mathrm{s} / \mathrm{he}$ is going to establish a non-government organisation (NGO) to create jobs for the people. In my opinion, such individuals take advantage of desperate communities to enrich themselves, because after some time the project does not exist and there is no trace of that particular person.

This should not be the case as organisations are required to register in terms of the Nonprofit Organisations Act No. 71 of 1997 (Department of Welfare, 1997).

After the collapse of a project, communities frequently felt deceived and betrayed and were suspicious of strangers wanting to initiate projects in their areas. The lack of accountability to the community was perceived as a major problem. Conversely, due to the high unemployment rate, other community members were still willing to try their hand at any opportunity that presented itself.

The lack of employment opportunities was a major factor at the root of the vulnerability of villagers. As a result of the recurring drought, many families were unable to cultivate their land for subsistence farming. Thus some families were dependent for their survival upon grandparents who received social grants. The majority of the participants stated that teenage pregnancy was on the increase as it was assumed that learners opted to have children in order to get the Child Support Grant (CSG). Further research is needed to establish whether there is indeed a link between high teenage pregnancy and the CSG. The participants also reported that educators' were concerned about these learners: "Educators are unhappy about the tendency of female learners and their boyfriends skipping school to collect the Child Support Grant." Participants noted that some teenage mothers dropped out of school as a result of childcare responsibilities. Male teenagers were more inclined to gravitate towards cities where they encountered challenges such as homelessness, being unpaid for menial jobs, risk of sexual molestation by unscrupulous adults, and of contracting HIV and AIDS. Their inadequate education minimises their chances of finding employment and they end up trapped in the cycle of poverty.

\section{Resistance to income-generating projects}

According to the majority of the participants, some businessmen - who enjoyed a monopoly and enormous support from traditional leaders and prominent villagers - viewed some of the incomegenerating projects as a threat to their businesses, such as the sale of live chickens or the establishment of a poultry farm. Some businessmen objected to income-generating ventures such as these and thus thwarted these community development initiatives.

\section{Lack of consultation and transparency}

The participants felt that community involvement and participation in existing and unsuccessful projects was undemocratic, since not all villagers were consulted or afforded the opportunity to elect their own representatives or committees. Committee members were usually handpicked by the initiator(s) of the project. In other instances, community members became aloof as a result of the politicisation of projects.

\section{Power issues}

The most fundamental problem that seems to bring divisions in communities is the power struggle between traditional and political leaders. The participants mentioned that most of the communities were in a dilemma as some felt that they owed their allegiance to traditional leaders, while others viewed them as old, conservative and resistant to change, and blamed them for impeding development in their communities. Conversely, political leaders were perceived as young, progressive, powerful and able to bring about the required changes to improve people's quality of life. 


\section{Insecurity, vulnerability and the high crime rate}

The majority of the participants attributed the escalating rate of crime in rural areas to unemployment, while others simply regarded it as a wave of criminal activities currently taking place in South Africa. The vandalising of public property and housebreaking were perceived as factors responsible for the failure of some projects. They also discouraged communities from embarking on income-generating projects. Generally, villagers no longer felt safe, especially the elderly, who were particularly vulnerable. Recently, there had been a spate of gruesome murders of the elderly by youngsters known to the victims. In cases known to the participants the motive was to steal the elderly persons' social grants. The communities' insecurities - which were likely to lead to powerlessness - were compounded by the fact that the South African Police Services were located very far from most villages. Reasons advanced for criminal behaviour varied from apartheid, poverty, deviancy to lack of positive role models, since most professionals had moved to Polokwane city. Lack of development in these areas was likely to tarnish the community spirit in such communities, as the elderly were no longer valued and had become a target for teenagers with maladaptive behaviour.

\section{Lack of collaboration among professionals}

The participants highlighted the lack of teamwork among professionals and the lack of support from relevant government departments as issues of concern. Many participants were of the opinion that only a few professionals - educators and the clergy - were vocal in their localities. They were of the opinion that it was the responsibility of all educated people to join forces in community matters in order to protect communities against dishonest people who would like to take advantage of them. Another challenge mentioned related to sewing projects which experienced difficulty in locating sustainable markets for their goods. Participants contended that professionals could assist in this regard.

\section{Poor government support}

Generally, the participants indicated that there was a lack of collaboration among various government departments, who provided little support to existing projects. Adequate support was required to ensure the success of income-generating projects, since most of the project members were in dire need of assistance in accessing funds, capacity building and project management, so as to increase the project's chance of success. However, most local government official charged with the responsibility of facilitating economic development in their municipalities lacked proper knowledge and skills.

\section{IMPLICATIONS FOR PRACTICE}

Impoverished rural communities are faced with myriad challenges and a well-conceived strategy is required to facilitate entry into embattled rural communities, where power struggles between traditional and political leaders are seriously thwarting development efforts. Makofane and Nuntsu (2001) reported on the adverse impact of leadership struggles on UNIN students' fieldwork practice. As regards suggestions for improvement, the participants recommended the following to policy makers in the Limpopo Department of Health and Social Development:

1. Introduce two-year mandatory community service for all qualified social workers to be based in rural areas after completion of their studies. In this way communities would be assured of access to social services.

2. Play a pivotal role in initiating a process of reviewing social work salaries to make them attractive to professionals so that they would settle in rural areas. 
3. Encourage social workers to collaborate with community workers in forming partnerships with traditional and political leaders, churches, women's clubs, community structures and schools in establishing community projects. This process would afford social workers an opportunity to market their services, as communities were currently unable to distinguish between social workers and community developers.

4. Ensure that, before funding is allocated to community projects, social workers have ascertained that a needs assessment has been conducted; that projects are inclusive and have followed a transparent democratic process in the election of committee or board members.

5. Urge social workers to play the role of catalyst, resource developer, activist, coordinator, facilitator, broker and advocate in promoting partnerships and curbing the duplication of services. The cooperation and collaboration of all partners is critical in bringing about positive transformation in rural communities.

6. Join students in challenging academics and practitioners to develop and produce local, culturally relevant literature that would be relevant to South African rural communities, since the adaptation of Western theories and models of service delivery posed a major challenge to social work students and novice professionals.

Clearly, further research of this nature is needed. Participatory action research is an ideal strategy for gaining the community's confidence and trust (Van Rooyen \& Gray, 1995). Most importantly, in participatory action research the community's collective generation of knowledge leads to the planning and enhancement of jointly created objectives (Collins, 1999:2; Long, 2001:7). According to Collins (1999:2), "the objectives are often for political ends, but may also be for organizational change, project management, community development and personal growth, or any other objectives the participants decide upon." This process would undeniably harness feelings of ownership and lead to the empowerment of rural communities as opposed to their exploitation through the imposition of others' views and values. Participatory action research could also serve as a foundation for the establishment of partnerships in social development. The goal of partnerships is to strategically combine efforts to alleviate poverty, address inequities and social injustices through the redistribution of resources and social and economic development programmes (Lombard \& Du Preez, 2004:232). Clearly, there is a need for local, culturally appropriate community-based solutions and this is what social work must provide, if it is to be relevant in rural contexts.

\section{CONCLUSION}

This exploratory study highlighted some of the problems and challenges of rural community development. Evidently little has been accomplished through development projects in impoverished rural areas and residents' quality of life has not improved as they believed it would after twelve years of democracy. Most importantly, the enormous task of social development in the rural areas of Limpopo province requires massive input from the government and private business sector. Developmental social work can do little more in such circumstances than play an ameliorative role, though it would seem that the future social workers involved in this study believed that they did have a role in rural community development. Hopefully policy makers in the provincial Department of Health and Social Development charged with this responsibility will take note of their enthusiasm and collective suggestions. 


\section{REFERENCES}

ARROSSI, S., BOMBAROLO, F., HARDOY, J., MITLIN, D., COSCIO, L.P. \& SATTERTHWAITE, D. 1994. Funding community initiatives. London: Earthscan Publications Ltd.

BOTES, L. \& VAN RENSBURG, D. 2000. Community participation in development: Nine plagues and twelve commandments. Community Development Journal: An International Forum, 35(1):41-58.

BROWN, M.J. 1999. The plight of rural elderly in South Africa: A case for a community development cadre? Community Development Journal: An International Forum, 34(2):143-150.

COLLINS, K. 1999. Participatory research: A primer. Johannesburg: Prentice Hall (Pty) Ltd. DEPARTMENT OF WELFARE. 1997. Nonprofit Organisations Act, Act 71 of 1997. Government Gazette No. 18487. Pretoria: Government Printer.

GOODLAND, R. \& LEDEC, G. 1987. Neoclassical economics and the principles of sustainable development. Ecological Model, 38(19).

LAWN, P.A. 2001. Toward sustainable development: An ecological economics approach. London: International Society for Ecological Economics.

LOMBARD, A. 1992. Community work and community development: Perspectives on social development. Pretoria: HAUM-Tertiary.

LOMBARD, A. \& DU PREEZ, J. 2004. Challenges for building partnerships in social development. Social Work/Maatskaplike Werk, 40(3):232-245.

LONG, C. 2001. Participation of the poor in development initiatives: Taking their rightful place. London: Earthscan Publications Ltd.

MAKOFANE, M.D.M. 1998. Belief systems as obstacle towards development of rural women and its implications for social work practice. Social Work/Maatskaplike Werk, 2(34):230-235.

MAKOFANE, M.D.M. \& NUNTSU, N.R.M. 2001. Community development projects: Leadership and power issues in a rural community. Paper presented at the Joint Universities Committee on Social Work Conference, University of Port Elizabeth, RSA.

MINISTRY FOR WELFARE AND POPULATION DEVELOPMENT. 1997. White Paper for Social Welfare. Government Gazette, Vol. 386. No. 18166. Pretoria: Government Printer.

NARAYAN, D. 1995. Designing community based development. Social Development Family of the World Bank: Washington, DC.

NEL, E. \& BINNS, T. 2000. Rural self reliance strategies in South Africa: Community initiatives and external support in the former homelands. Journal of Rural Studies, 16(3):367-377.

SOUTH AFRICAN INSTITUTE OF RACE RELATIONS. 2004. South Africa Survey 2003/2004. Johannesburg: South African Institute of Race Relations.

VAN ROOYEN, C.A.J. \& GRAY, M.M.A. 1995. Participatory research: Compatibility to social work. Social Work Researcher/Practitioner, 8(2):3-8.

Mankwane Makofane, Associate Professor, University of Limpopo, Turfloop, South Africa; Mel Gray, Professor of Social Work, University of New Castle, New South Wales, Australia. 